\title{
Setting acceptable prices: a key for success in retailing
}

\section{Setting acceptable prices}

\section{Fijación de precios aceptables: clave para el éxito en el comercio detallista}

\author{
F. Javier Rondan-Cataluña and Bernabe Escobar-Perez \\ University of Seville, Sevilla, Spain, and \\ Manuel A. Moreno-Prada \\ Nova Maracana Group, El Viso Del Alcor (Sevilla), Spain
}

\begin{abstract}
Purpose - This research enables the authors to highlight the importance of proper pricing for retailers. The purpose of this paper is to demonstrate the importance of demand-based pricing, providing empirical results that reveal the validity of this pricing philosophy in the sport retailing industry. In particular, this study has identified the limits of acceptable prices for the products studied, selected the most appropriate method for pricing products suffering from high competition and compared the impact produced on price perceptions according to different retail environments to be able to relate changes in the acceptable prices ranges according to the geographical location of each point of sale, differentiating between rural or urban environment and type of client.
\end{abstract}

Design/methodology/approach - The authors have carried out surveys of 350 customers in each of the three points of sale analysed. Therefore, there are a total of 1,050 interviewees, for the three products analysed. The direct method of acceptable prices setting is developed. In addition, ANOVA and $t$-test have been carried out to find differences between the three shops.

Findings - One main finding is that the acceptable price range is not unique. Each point of sale has one that is distinct because it depends on many factors: the competition, the economic capacity of the closest residents, the location of the point of sale or the ability to attract customers.

Originality/value - The foremost contribution of this paper is to demonstrate empirically how considering the local demand at setting prices would generate larger earnings, even for a small retail chain. The direct method of setting acceptable prices enables us to set the prices according to the demand. The best option is if these prices are above the costs. It can be noted that the prices should be set according to each shop, and a different price used in each point of sale to maximise profits and to adapt to what the typical customer of each shop is willing to pay, despite the products being the same and the points of sale belonging to the same retail chain.

Keywords Retailing, Demand, Price range, Pricing

Paper type Research paper

(C) F. Javier Rondan-Cataluña, Bernabe Escobar-Perez and Manuel A. Moreno-Prada. Published in Spanish Journal of Marketing - ESIC. Published by Emerald Publishing Limited. This article is published under the Creative Commons Attribution (CC BY 4.0) licence. Anyone may reproduce, distribute, translate and create derivative works of this article (for both commercial and noncommercial purposes), subject to full attribution to the original publication and authors. The full terms of this licence may be seen at http://creativecommons.org/licences/by/4.0/legalcode

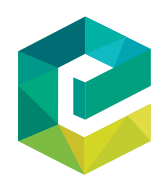

Spanish Journal of Marketing ESIC 


\begin{abstract}
Resumen
Objetivos - Esta investigación nos permite resaltar la importancia de una fijación de precios adecuada para los minoristas. El objetivo principal de esta investigación es demostrar la importancia de la fijación de precios basada en la demanda, proporcionando resultados empíricos que revelan la validez de esta filosofía de fijación de precios en el sector minorista de productos deportivos. En particular, en este estudio se han identificado los intervalos de precios aceptables para los productos estudiados; se ha seleccionado el método más apropiado para la fijación de precios de productos que sufren alta competencia; y se ha comparado el impacto en las percepciones de precios según el entorno detallista y se han encontrado cambios en los intervalos aceptables de precios en función de la localización geográfica del punto de venta, diferenciando entre entorno rural y urbano, y el tipo de cliente.
\end{abstract}

Metodología - Los autores han realizado encuestas a 350 clientes en cada uno de los 3 puntos de venta analizados. Por lo tanto, hay un total de 1050 entrevistados, para los 3 productos analizados. Se desarrolla el método directo de fijación de precios aceptables. Además, se han realizado pruebas ANOVAs y T para encontrar diferencias entre las 3 tiendas.

Resultados - Un hallazgo principal es que el intervalo de precios aceptable no es único. Cada punto de venta tiene uno distinto porque depende de muchos factores: la competencia, la capacidad económica de los residentes más cercanos, la ubicación del punto de venta o la capacidad de atraer clientes.

Originalidad/valor - La principal contribución de este artículo es demostrar empíricamente cómo considerar la demanda local al establecer precios generaría mayores ganancias, incluso para una pequeña cadena minorista. El método directo de establecer precios aceptables nos permite establecer los precios de acuerdo con la demanda. La mejor opción es si estos precios están por encima de los costos. Se puede observar que los precios deben establecerse de acuerdo con cada tienda, y se debe usar un precio diferente en cada punto de venta para maximizar los beneficios y adaptarse a lo que el cliente típico de cada tienda está dispuesto a pagar. A pesar de que los productos son los mismos y los puntos de venta pertenecientes a la misma cadena minorista.

Palabras clave - Fijación de precios, Precios aceptables, Sector minorista, Demanda, Intervalo de precios Tipo de artículo - Trabajo de investigación

\title{
1. Introduction
}

At the dawn of marketing, McCarthy showed that the price, along with the product, the point of sale and the promotion are the four classic variables on which Marketing is centred (Mccarthy, 1964). Specifically, the price is the variable via which it is meant to fulfil the value in the market that is created by the other three. In research within the retail business, price setting is one of the subjects which is most printed in the main journals that tend to publish scientific articles in this sector (Finnegan et al., 2016; Fassnacht and El Husseini, 2013). Price is not the only determining factor in a consumer's decision-making process (Ruiz-Real et al., 2018), but in many retail sectors is quite relevant. Academic discipline of marketing gives the impression to have fallen over affecting positive change in practical pricing practice. This gap will involve pricing marketing academics to work with retailers and price practitioners to understand their daily requests (Watson et al., 2015). This study tries to help filling this gap with.

Thus, price setting is a process of foremost importance and complexity, as it must consider the firm's environment and the competition. It must also bear in mind the repercussions which it entails, highlighting those that are financial, commercial and strategic (Cebollada-Pascual and Mugica-Grijalba, 1997). In general, pricing decisions are affected by cost information, consumer buying behaviour, and competition (Uusitalo and Rökman, 2007). In daily practice, the optimal price is rarely known by managers because of the extensive variety of factors that can influence the consequences of a pricing decision (Rusetski et al., 2014). Especially service firm executives should pay more attention to product price to appeal to customers (Chang and Wong, 2018). Perhaps because of this idea, price setting continues being a controversial question, as is shown by the multitude of methods to carry it out. Fundamentally based on the cost, on the demand and on the competition. Among the methods based on the demand, this study analyses that of acceptable price setting. To 
know the limits that the customer is willing to pay for firms' products is very important for companies. That is to say, the interval of acceptable prices within which supply and demand has more likelihoods of coinciding (Rosa-Díaz et al., 2013).

It is difficult to find empirical works in the specialised literature which put into practice this method of setting prices and even more so in the retail business. This is probably because it is hard to get the necessary information.

The management of price strategies in distributing companies is especially problematic and complicated with respect to the rest of the industries. This is because of different causes (Rosa-Díaz et al., 2013):

- Prices must be determined for thousands of very diverse goods.

- The price aims of the makers can be very different from the price aims of the intermediaries.

- The prices of the products influence their own sales and those of the competing and complementary goods of the same establishment.

- An image of integral prices of the chain must be conceived from the prices of thousands of products.

Therefore, this investigation reveals the relevance of an appropriate price setting for the retail business. The main purpose of this research is to demonstrate the importance of demand-based pricing, providing empirical results that reveal the validity of this pricing philosophy in the sport retailing industry. Specifically, this study:

- identifies the limits of acceptable prices for the products studied;

- chooses the most appropriate method for the price setting of products that are highly competitive with similar products; and

- compares the impact produced according to the different environments of the points of sale to be able to relate the variations of the price ranges of acceptable prices according to the geographical location of each point of sale, differentiating between rural or urban environment, and types of consumers.

The main contribution of this paper is to show empirically how considering the local demand at fixing prices would produce bigger incomes, even for a small retail chain. The advantages of demand-based pricing are well documented in terms of customer satisfaction and loyalty (Heo et al., 2013; Kimes and Wirtz, 2002). However, the studies of the effects of these pricing policies from the offer perspective are underdeveloped.

To carry out this study, the authors have had access to a small family firm which has three points of sale in the province of Seville (Spain) - one in a rural zone with a low population density and the other two in urban zones within high-density cities. Three standard quality products have been analysed: a tracksuit, a football kit and running shoes. They are of an unknown brand, so the brand effect does not affect the price analysis, and they have a lot of competition. The customers have been interviewed and their reactions to price changes have been measured as well as the differences by sex, age and the type of environment where the shop is located.

The rest of the work is structured as follows. In Section 2, the investigation's theoretical framework is outlined. In Section 3, the methodology used is dealt with. In Section 4, the main results are presented. Section 5 gives the discussion, and in Section 6, the conclusions are drawn. 
SJME

23,1

\section{Theoretical framework}

The price is the value which each seller requires in exchange for a product or a service, the customer being who decides to accept it or not. The success of a pricing strategy depends upon customers being willing to pay the price you charge (Nagle and Müller, 2017). In the traditional conception of the economy, the price appears as a given element which contrasts with the current view of the price as a very important decision factor, and which has given rise to different research lines in Marketing. Moreover, price setting in the retail business is especially complex because of the great quantity of products which are sold and which therefore need sales prices (Rosa-Díaz et al., 2013).

Customers form an expectation of the product when they acquire it and evaluate it with a reference price that they expect to pay for the acquisition. The reference price is the price stored in a consumer's mind that serves as a point of comparison for future purchases and denotes the price that he/she considers a product should cost (Kimes and Wirtz, 2002; Unni et al., 2010). Consequently, the reference price is the price that the customer applies to compare and resolve whether a product is expensive or cheap (Gupta and Kim, 2010; Monroe, 1973). The customer establishes the reference price based on information about previous prices, contextual variables and future price expectations when making a purchase decision, considering the economic conditions, consumer characteristics, feelings and all the information available at the time of choosing (Verhoeven et al., 2009). Furthermore, the reference price is expected to be within the acceptable price range, and price limits are slightly "shaped" by the prices to which they are exposed all through their shopping event (Kosenko, 2015). The role of reference price on some purchase issues such as store choice should be examined (Mazumdar et al., 2005), and the study of prices based on demand in relation to the type of store could put some light on this issue of store choice.

The topics that form the literature background of this research are the price strategies in the retail business, the setting of acceptable prices and price range and demand-based pricing. The following subheadings are dedicated to these issues.

\subsection{Price strategies in the retail business}

Price setting is not to simply set the monetary quantity for the buyer to pay in a future purchase, but has numerous consequences in the market, on the competition, etc. It can also become a fundamental part of a strategy which considers the characteristics of the product, market, distribution system, etc. In addition, this variable together with product selection and atmosphere are important attributes on choosing retail grocery formats (Carpenter and Moore, 2006).

The design of the pricing strategy is very important, as it has to be taken into account in the development of the firm's aims, the market situation and flexibility (Nagle et al., 2016). A multitude of factors exist for price setting: costs, competition, market, demand and psychology.

Many different aspects of pricing strategy have been dealt with in the retailing arena. Some relevant issues related to new technologies are pointed out revising recent literature about this topic. For example, Menon et al. (2016) demonstrated the U-shape of the function for fixations on price using eye tracking on a Facebook page that showed clothes. Furthermore, related to new technologies, other researchers studied how blogs and online discussion boards could conduct to price discounts in one channel rising product recognition in other competing sales channels, therefore decreasing or even inverting the cannibalisation consequences (Verhoef et al., 2015). In addition, recent research proved that the position of the sale price in displays and communications online could have substantial influences on customers' price perceptions (Grewal et al., 2017). According to this idea, one of the findings 
of Roggeveen et al. (2015) is that buyers exposed to dynamic presentation formats become less price sensitive. Other researchers suggested and tested a best-response pricing strategy through a controlled live experiment in online retailing to respond competitors' price changes (Fisher et al., 2017). However, studies related to traditional brick and mortar retailers, like this one, are scarce nowadays. In this area, a study demonstrated that probabilistic and markdown selling strategies operate as price discrimination instruments by presenting consumers a possibility to obtain some products or services (Rice $e$ t al., 2014).

On the other hand, differential strategies are those in which prices are set considering the differences between consumers. These differences can be demographic characteristics, location, temporal and socio-economic.

For this type of strategies, the following conditions have to be given:

- The market must not be homogenous, there existing different consumers with their own price elasticities.

- Discriminatory prices must be legal.

- There is the possibility of setting different prices without producing dissatisfaction in some consumers.

Price discrimination for the same product according to some of the factors which have been mentioned can give rise to achieving greater profitability or profits than those that could obtain selling everywhere at the same price (Rice et al., 2014). Examples of discrimination can be the difference of prices between the north and the south of a country. There are firms in which the same tracksuit, or any other product, can have an acceptable price quite higher in the north than in the south (Rondán Cataluña, 2004), or between shops with different competitive environments even in the same chain. This is because the characteristics of the customers of a shop's environment are going to influence their perception of prices (Macé, 2012). Furthermore, some authors concluded that price elasticity by buyers may vary across store setting and store type (Huddleston et al., 2009).

In this group of strategies, the following can be differentiated:

- Strategies based on fixed or variable prices: This is based on the product being sold to all the customers at the same price and in the same conditions. This strategy tends to be common in products with a great movement and a low price. In the items with unaffordable prices or of the services sector, these are likely to be variable as they are usually subject to negotiation in every transaction.

- Discount depending on the quantity: This is a strategy followed by some firms to achieve greater sales via a reduction in the price according to the quantity. This quantity-based price is non-linear.

- Discount for advance payment: The payment in the market is a variable to be considered by the firm. This strategy awards advance payment with a discount on the price. It is not a fixed price but varies according to each firm.

- Deferred payment: Unlike with early payments, in this case, the buyer does not pay in cash or in little time but requests a payment at later dates. The possibility of doing so is the firm's decision and if it is done there is a penalisation in the form of a surcharge or of deferred interest payments. It is a way to encourage sales, as it does not limit the buyer to having the necessary amount at the moment of purchase - this purchase can be paid later, after the sale has been made. 
SJME

23,1

- Discounts in the form of offers: With these types of strategies, firms can capture new customers via decreasing prices without prior knowledge. This price reduction should be studied for the money which will not be gained because of lowering the price to be compensated by the increase in the number of sales.

- Seasonal discounts: Unlike the latter, these price decreases are foreseen, and consumers know about them. They are fixed by periods of time or seasonal sales. With sales or periodical discounts, firms manage to reach two kinds of costumers with different demand elasticities. There are customers who are less price-sensitive and buy in periods without discounts and there are other customers whose price sensitivity is high and who prefer to buy in discount periods. The quality of the product is the same; the channel can also be the same, only the price varies, which is why its sensitivity is high.

- Discounts in the second market: Called second market to distinguish between being within the market of some consumers with respect to others. These consumers will access a price with a discount that is different from that of the rest of the consumers. To do so, they must fulfil a series of demographic or socio-economic characteristics which will be fixed by the firm. This price difference means discrimination according to the consumer's demographic or socio-economic characteristics. Examples of these discounts are civil servants, the unemployed, the retired, etc.

- Prices of professionals: Specific professionals, such as doctors, lawyers, economists, etc., set standard prices for a series of services, irrespective of the time needed to provide them. This gives the consumer a greater clarity.

- Ethical prices: There are products used with social aims, which are fixed with a price in accordance with the buyer's capacity. They tend to be necessities, to which ethically the consumer should be able to have access.

On the other hand, competitive strategies are based on competition through prices. Managers can seek a reaction in favour of their firms and against their competitors, lowering, equalling or raising prices.

In the face of a highly competitive market and very tight prices between competitors, care must be taken concerning a sharp fall in prices. To do so gives rise to a price war which does not benefit anyone.

If the product which a firm offers is superior to those of its competitors, such as a higher quality or having additional services, we may set higher prices than the competition. These prices are called "primed" or "premium" prices.

On the other hand, if our product has a lower quality, we will opt for a strategy of low prices. This strategy can also be used to seek scale economies, raising sales to a rhythm capable of generating an exponential growth of profits. This policy is currently used a great deal in Internet and massive purchases.

It is easy to understand that for the price of the product to increase because of an increase in the product's quality, it is necessary for the consumer to able to perceive it.

As well as these strategies, there are also "loss-making sales", which, as their name implies, consists of selling below the cost price to obtain promotion, clearance sales, stock clearance, and even harming or eliminating competitors.

\subsection{Setting acceptable prices and price range}

For all firms, it is important to set prices to achieve an interval within which their product has an acceptable price. This is essential for survival and growth, as all prices outside this 
interval will cause minimum or null sales or, in other words, reduce the demand of the product to the minimum. Price acceptance is founded on the assimilation-contrast theory (Sherif et al., 1958). This theory proposes that a recent stimulus met by a person is ruled on compared to a background of preceding experience in the category. Studies in this arena has employed the assimilation-contrast theory to price perceptions and suggested latitude of price acceptance (Kalyanaram and Little, 1994; Martín-Consuegra et al., 2007). The level of price acceptance can consequently be described as the maximum price that a consumer is able to pay for the product or service (Monroe, 1990).

The acceptable prices interval is the set of prices within some limits in which the supply receives a response from the demand. These are represented in the higher level as excessively unaffordable prices and in the lower level as excessively low prices (Rosa-Díaz et al., 2013).

The variation of the price within this interval generates an impact on the demand. A lower price is going to produce an increase in the demand. However, if it is excessively low this can cause the consumer to consider a loss of quality, which leads to a decrease of the demand. On the other hand, an excessively high price can make the consumer consider that the product is expensive and the demand will also decrease (Karani et al., 2013).

To analyse the variations of setting - the increase or decrease of the price-our study will centre on a definition, the "acceptable price range". This interval varies according to the economic situation of the market. In moments, downturn price wars are intensified (thus reducing the interval). Although when there is an economic boom, the interval is broadened and the price loses importance to other marketing variables (Pelegrin-Borondo et al., 2014). For example, during an economic crisis there is an upsurge of customers in the factory outlet stores. This indicates that the customer gives less importance to the product being new or of a worse quality. This increases the impact of a correct price setting in the crisis period in which the price variable has a preferential value.

The range of price acceptation is a term made up of two dimensions, defined as a "level dimension" (the price level at which the price acceptation zone is extended) and by a "breadth dimension" (the breadth of the latitude of acceptation). Consequently, customers take as a reference a zone in which are circumscribed a continuous series of prices which they believe are acceptable for the level of quality of the good considered. This thus establishes the set of prices which they are willing to pay. The prices outside this zone are, being too low or too high, estimated to be unsatisfactory and therefore unacceptable. The presence of a lower limit for a product's acceptable price range implies that the customer carries out associations between the price and the quality of the good (the levels of excessively low prices are different from an insignificant quality). On the other hand, the upper limit of the acceptable price range embodies the higher value that the customer is willing to pay for the product (Rosa-Díaz et al., 2013).

Although the sales volume or offer is set by not only the product's price but also numerous variables (competition, sales, force, advertising, distribution, product, etc.), it is true that most of the retail business centres its marketing strategy on the price. As has happened traditionally and still now, because of the scant development of this sector and its marketing managers (Rosa-Díaz and Rondan-Cataluña, 2012).

In the background of price evaluations, latitude of acceptance is made up of an acceptable price range around a reference point. The price differences falling within consumers' acceptable price ranges are accepted, when price differences fall outside the acceptable price range, they are rejected (Heo et al., 2013). At some point above the reference price, some buyers will find the good too expensive and stop purchasing, this is the upper absolute price threshold. On the contrary, at some position where the price is so low that some customers 
SJME

23,1

notice it to be too low and become doubtful of its quality, they would also cease purchasing, this is the lower absolute price threshold. Therefore, the upper and lower absolute price thresholds form the range of prices a specific consumer would consider buying (Monroe et al., 2015). Accumulating purchasers for a specific product would generate a distribution of prices that are intolerable as they are seen to be too low and another distribution of prices that are intolerable because they are remarked to be too high. If price-market segments exist, each group of buyers is categorised as having fluctuating price elasticities at these specific low and high price thresholds (Monroe et al., 2015; Pauwels et al., 2007). This reasoning reveals the importance of proving practically the existence of these specific segments for the same products at the same retail chain, and the necessity for managers to base their price decisions on demand-based pricing. Some authors (Srinivasan et al., 2008; Calabrese and De Francesco, 2014) affirmed that demand-based pricing is associated with higher retailer and service providers gross margins, enhanced the understanding of variation in the patterns of price adjustment. In addition, some consumers are willing to pay premium prices if these are consistent with their perceived value about a service or a retailer (Calabrese and De Francesco, 2014), but how much are they willing to pay? This question needs further research.

According to the previous ideas the research question formulated in this study is:

RQ1. Can be demonstrated empirically if considering the local demand at setting prices would generate larger earnings, even for a small retail chain?

\section{Methodology}

To carry out the study, the authors have opted for the direct method of acceptable prices setting as being the most appropriate to set the price (Rosa-Díaz, Rondan-Cataluña and Diezde Castro, 2013; Dodds, Monroe and Grewal, 1991). This is based on two fundamental proposals:

(1) Above a certain price, the consumer has the impression that the product is too expensive.

(2) Below a certain price, the consumer has the impression that the quality of the product is bad.

Having proposed these fundamental principles, the method enables finding the price range which they delineate. To do so, it is necessary to formulate the following questions:

- Below what level of prices, among those which are indicated, do you consider that the product has an unacceptably low quality? Therefore, what is the minimum price level that you would be willing to pay for this product?

- Above what level of prices, among those which are indicated, do you consider that the product is excessively expensive? Therefore, what is the minimum price level that you would be willing to pay for this product?

These questions were asked to 350 interviewees in each of the three points of sale. Therefore, a total of 1,050 interviewees were collected related to the three products analysed. Data collection took place between the months of October 2015 and January 2016. These were personal surveys of customers inside the shops in question. It is a non-random sampling method aimed at the customers who wished to answer the questionnaire. The 56.29 per cent of the sample were males, 34.19 per cent respondents were under 30 years old, 54 per cent between 30 and 60 years old and 11.81 per cent over 60 . 
For each level of price, the number of interviewees who set it as the minimum acceptable level and maximum acceptable level was calculated. Later, the accumulated percentage of the possible buyers compared to the minimum price was determined, and, contrariwise, the accumulated percentages of the possible non-buyers regarding the maximum price. The difference between these accumulated percentages is the percentage of possible buyers. In addition, the difference between the two levels is the maximum difference and is considered as the most appropriate price level.

The firm in our study is a small family company with three points of sale of sport products in the province of Seville (Spain). One of them is in a small town, a rural zone with a low population density and an average net income declared in 2016 of $€ 15,527$ per person (Shop 2), and the other two in two cities, high-density urban zones. One is in a factory outlet store (Shop 1) the average net income declared in this city in 2016 was $€ 18,255$ per person, and the other in a commercial/tourist area of the main town (Shop 3) the average net income declared in this main city in 2016 was $€ 21,524$ per person, according to the Statistic Institute of Andalusia. As well as these characteristics, information about the sizes of the shops was analysed, which are from $900 \mathrm{~m}^{2}$ - the largest - to $250 \mathrm{~m}^{2}$ - the smallest. The sales volume of this firm during the last fiscal year was approximately 2 million euros.

For the study, three products were analysed: a tracksuit, a football kit and running shoes. They are of a standard quality and there is a lot of competition from related products. In addition, the authors collected information disclosed by the firm about sales for the three products in the three shops at three price levels in three weeks in February 2016.

\section{Results}

Now, the results obtained in the surveys carried out in the shops are presented. There were 1,050 surveys, 350 for each shop. The minimum prices which the interviewees consider an acceptable price for the football kit are shown in Table I.

The minimum price ranges from $€ 3$ to $€ 13$ and the average price is close to $€ 7$. The Table I also reflects the frequency of the different prices. With these results, the acceptation or the rejection of the different prices for this product can be obtained.

Table II indicates the maximum price which the interviewees would be willing to pay for the product. The frequency, the percentage of the frequency with respect to the total and the interviewees' acceptation or rejection of each price is also noted.

Regarding gender, significant differences for men and women in the average maximum and minimum prices suggested by the interviewees are not found. The data obtained via the

\begin{tabular}{|c|c|c|c|c|c|}
\hline Minimum prices & Freq. & $(\%)$ & Accept. & Rejec. & \\
\hline \multicolumn{6}{|l|}{ Euros } \\
\hline 3 & 5 & 0.5 & 0.5 & 99.5 & \\
\hline 5 & 169 & 16.1 & 16.6 & 83.4 & \\
\hline 6 & 171 & 16.3 & 32.9 & 67.1 & \\
\hline 7 & 232 & 22.1 & 55.0 & 45.0 & \\
\hline 8 & 129 & 12.3 & 67.2 & 32.8 & \\
\hline 9 & 139 & 13.2 & 80.5 & 19.5 & \\
\hline 10 & 188 & 17.9 & 98.4 & 1.6 & \\
\hline 12 & 16 & 1.5 & 99.9 & 0.1 & Table I. \\
\hline 13 & 1 & 0.1 & 100.0 & 0.0 & Minimum price for \\
\hline Total & 1,050 & 100.0 & & & the football kit \\
\hline
\end{tabular}




\begin{tabular}{|c|c|c|c|c|c|}
\hline & & & & & \\
\hline 231 & Maximum prices & Freq. & $(\%)$ & Accept. & Rejec. \\
\hline & Euros & & & & \\
\hline & 7 & 2 & 0.2 & 0.2 & 99.8 \\
\hline & 8 & 14 & 1.3 & 1.5 & 98.5 \\
\hline & 9 & 45 & 4.3 & 5.8 & 94.2 \\
\hline & 10 & 111 & 10.6 & 16.4 & 83.6 \\
\hline 128 & 11 & 49 & 4.7 & 21.0 & 79.0 \\
\hline & 12 & 136 & 13.0 & 34.0 & 66.0 \\
\hline & 13 & 98 & 9.3 & 43.3 & 56.7 \\
\hline & 14 & 150 & 14.3 & 57.6 & 42.4 \\
\hline & 15 & 199 & 19.0 & 76.6 & 23.4 \\
\hline & 16 & 76 & 7.2 & 83.8 & 16.2 \\
\hline & 17 & 49 & 4.7 & 88.5 & 11.5 \\
\hline & 18 & 59 & 5.6 & 94.1 & 5.9 \\
\hline & 19 & 32 & 3.0 & 97.1 & 2.9 \\
\hline & 20 & 21 & 2.0 & 99.1 & 0.9 \\
\hline & 21 & 3 & 0.3 & 99.4 & 0.6 \\
\hline & 22 & 3 & 0.3 & 99.7 & 0.3 \\
\hline Table II. & 24 & 2 & 0.2 & 99.9 & 0.1 \\
\hline Maximum price for & 25 & 1 & 0.1 & 100.0 & 0.0 \\
\hline the football kit & Total & 1,050 & 100.0 & & \\
\hline
\end{tabular}

calculations comparing the interviewees' figures of minimum and maximum prices according to the shop are in Table III.

The descriptive statistics by shops for price minimum and maximum are also presented in Table III. After carrying out an ANOVA to verify the equality of measures for the three shops, there are significant differences between the average maximum and minimum prices suggested by the customers of the different shops. This result is corroborated by doing a non-parametric verification. The minimum price suggested by the customers of the Shop 2 is significantly lower than in the other two. In addition, with respect to the maximum price, the interviewees of each shop suggest different figures, the highest being for the Shop 3 - an average of almost $€ 16$ compared to the $€ 11.69$ suggested by the interviewees in the Shop 1 .

The importance of age when suggesting maximum and minimum prices is also studied. To do so, the respondents have been grouped as follows: under 30 years old, between 30 and 60 years old and over 60 years old (Table IV).

\begin{tabular}{lrrr}
\hline Shops & $N$ & Mean & SD \\
\hline Price min. ANOVA (F= 48.44; Sig = 0.000) & & & \\
Shop 1 & 350 & 6.76 & 1.642 \\
Shop 2 & 350 & 7.77 & 1.893 \\
Shop 3 & 350 & 7.97 & 1.682 \\
Total & 1,050 & 7.50 & 1.820 \\
Price max. ANOVA (F=307.26; Sig = 0.000) & & & \\
Shop 1 & 350 & 11.69 & 2.112 \\
Shop 2 & 350 & 13.80 & 1.759 \\
Shop 3 & 350 & 15.97 & 2.842 \\
Total & 1,050 & 13.82 & 2.873 \\
\hline
\end{tabular}

Table III.

Descriptive by shop for the football kit

Total 


\begin{tabular}{|c|c|c|c|c|}
\hline Age & $N$ & Mean & $\mathrm{SD}$ & $\begin{array}{l}\text { Setting } \\
\text { acceptable }\end{array}$ \\
\hline $\begin{array}{l}\text { Price min. ANOVA }(F=112.88 ; \text { Sig }=0.000) \\
<30 \\
30-60 \\
>60 \\
\text { Total }\end{array}$ & $\begin{array}{r}359 \\
567 \\
124 \\
1,050\end{array}$ & $\begin{array}{l}6.89 \\
7.46 \\
9.47 \\
7.50\end{array}$ & $\begin{array}{l}1.646 \\
1.741 \\
1.186 \\
1.820\end{array}$ & prices \\
\hline \multirow{2}{*}{$\begin{array}{l}\text { Price max. ANOVA }(F=129.01 ; \text { Sig }=0.000) \\
<30 \\
30-60 \\
>60 \\
\text { Total }\end{array}$} & \multirow[b]{2}{*}{$\begin{array}{r}359 \\
567 \\
124 \\
1,050\end{array}$} & \multirow[b]{2}{*}{$\begin{array}{l}12.57 \\
13.95 \\
16.85 \\
13.82\end{array}$} & \multirow[b]{2}{*}{$\begin{array}{l}2.816 \\
2.390 \\
2.665 \\
2.873\end{array}$} & $y$ \\
\hline & & & & $\begin{array}{r}\text { Table IV. } \\
\text { Descriptive by age } \\
\text { for the football kit }\end{array}$ \\
\hline
\end{tabular}

After doing an ANOVA to verify the equality of measures for the three age groups, there are significant differences between the average maximum and minimum prices suggested by customers of different ages. This result is corroborated by carrying out a non-parametric verification. The minimum price suggested by customers under 30 years old is significantly lower than that of the group of over 60 years old. With respect to the maximum price, the respondents of each age group suggest different maximum prices, the highest being those over 60 at an average $€ 16.85$, compared to the $€ 12.57$ suggested by the interviewees under 30.

Now, the results obtained for tracksuits are presented. First, the minimum prices including their frequency, acceptation and rejection (Table V).

Next, the maximum price suggested by the 1,050 interviewees for the tracksuit is shown (Table VI).

In Table VII, the measures of both prices and their standard deviations by gender are compared.

From the $t$ test comparing measures significant statistical differences appear for men and women in both the average minimum and maximum prices suggested. This idea is confirmed by the non-parametric test.

\begin{tabular}{|c|c|c|c|c|c|}
\hline Minimum prices & Freq. & $(\%)$ & Accept. & Rejec. & \\
\hline \multicolumn{6}{|l|}{ Euros } \\
\hline 5 & 34 & 3.2 & 3.2 & 96.8 & \\
\hline 6 & 58 & 5.5 & 8.8 & 91.2 & \\
\hline 7 & 148 & 14.1 & 22.9 & 77.1 & \\
\hline 8 & 172 & 16.4 & 39.2 & 60.8 & \\
\hline 9 & 180 & 17.1 & 56.4 & 43.6 & \\
\hline 10 & 245 & 23.3 & 79.7 & 20.3 & \\
\hline 11 & 106 & 10.1 & 89.8 & 10.2 & \\
\hline 12 & 69 & 6.6 & 96.4 & 3.6 & \\
\hline 13 & 23 & 2.2 & 98.6 & 1.4 & \\
\hline 14 & 3 & 0.3 & 98.9 & 1.1 & Table V. \\
\hline 15 & 12 & 1.1 & 100.0 & 0.0 & Minimum prices for \\
\hline Total & 1,050 & 100.0 & & 100.0 & tracksuits \\
\hline
\end{tabular}




\begin{tabular}{|c|c|c|c|c|c|}
\hline \multirow{2}{*}{$\begin{array}{l}\text { SJME } \\
23,1\end{array}$} & Maximum prices & Freq. & $(\%)$ & Accept. & Rejec. \\
\hline & \multicolumn{5}{|l|}{$\overline{\text { Euros }}$} \\
\hline \multirow{5}{*}{130} & 9 & 12 & 1.1 & 1.1 & 98.9 \\
\hline & 10 & 41 & 3.9 & 5.0 & 95.0 \\
\hline & 11 & 13 & 1.2 & 6.3 & 93.7 \\
\hline & 12 & 68 & 6.5 & 12.8 & 87.2 \\
\hline & 13 & 59 & 5.6 & 18.4 & 81.6 \\
\hline & 14 & 94 & 9.0 & 27.3 & 72.7 \\
\hline \multirow{12}{*}{$\begin{array}{l}\text { Table VI. } \\
\text { Maximum prices for } \\
\text { tracksuits }\end{array}$} & 15 & 279 & 26.6 & 53.9 & 46.1 \\
\hline & 16 & 138 & 13.1 & 67.0 & 33.0 \\
\hline & 17 & 109 & 10.4 & 77.4 & 22.6 \\
\hline & 18 & 81 & 7.7 & 85.1 & 14.9 \\
\hline & 19 & 41 & 3.9 & 89.0 & 11.0 \\
\hline & 20 & 73 & 7.0 & 96.0 & 4.0 \\
\hline & 21 & 11 & 1.0 & 97.0 & 3.0 \\
\hline & 22 & 23 & 2.2 & 99.2 & 0.8 \\
\hline & 23 & 4 & 0.4 & 99.6 & 0.4 \\
\hline & 24 & 3 & 0.3 & 99.9 & 0.1 \\
\hline & 27 & 1 & 0.1 & 100.0 & 0.0 \\
\hline & Total & 1,050 & 100.0 & & \\
\hline
\end{tabular}

\begin{tabular}{lccc}
\hline Gender & $N$ & Mean & SD \\
\hline Price min. $($ T test $=$ 5.31; Sig = 0.000) & & & \\
Males & 591 & 9.34 & 1.956 \\
Females & 459 & 8.70 & 1.886 \\
Price max. $($ T test $=4.64 ;$ Sig $=0.000)$ & & & \\
Males & 591 & 16.00 & 2.708 \\
Females & 459 & 15.20 & 2.813 \\
\hline
\end{tabular}

Next, the data obtained comparing the figures of minimum and maximum prices of those interviewees by shops are reproduced (Table VIII).

After calculating an ANOVA to assess potential differences for the three shops regarding the minimum and maximum prices of tracksuit, they reflect significant differences between the average prices suggested by the customers. This result is confirmed by carrying out a non-parametric test. The same as with the football kit, the minimum price suggested by the customers of Shop 1 is significantly lower than in the other two. In addition, with respect to the maximum price, each shop's interviewees suggest different maximum prices, the highest being those in the Shop 3 - more than $€ 18$ on average compared to the $€ 13.41$ proposed by the interviewees of the Shop 1. Having done the calculation per shop, the next step is to calculate the variation by age groups.

With the ANOVA, potential differences for the three age groups and for this product are analysed (Table IX). There are also significant differences between the average maximum and minimum prices suggested by buyers of different ages. This effect is corroborated by carrying out a non-parametric verification. The minimum prices suggested by customers under 30 years old and from 30 to 60 years old are significantly lower than those of the group of over 60 years old. And regarding the maximum price, those interviewees of each set of ages record different maximum prices, the costliest 


\begin{tabular}{|c|c|c|c|c|}
\hline Shops & $N$ & Mean & SD & setting \\
\hline $\begin{array}{l}\text { Price min. ANOVA }(F=76.74 \text {; Sig }=0.000) \\
\text { Shop } 1 \\
\text { Shop } 2 \\
\text { Shop } 3 \\
\text { Total }\end{array}$ & $\begin{array}{r}350 \\
350 \\
350 \\
1,050\end{array}$ & $\begin{array}{l}8.17 \\
9.15 \\
9.87 \\
9.06\end{array}$ & $\begin{array}{l}1.938 \\
1.669 \\
1.853 \\
1.951\end{array}$ & prices \\
\hline $\begin{array}{l}\text { Price min. ANOVA }(F=76.74 \text {; } \text { Sig }=0.000) \\
\text { Shop } 1 \\
\text { Shop } 2 \\
\text { Shop } 3 \\
\text { Total }\end{array}$ & $\begin{array}{r}350 \\
350 \\
350 \\
1,050\end{array}$ & $\begin{array}{l}13.41 \\
15.49 \\
18.04 \\
15.65\end{array}$ & $\begin{array}{l}2.140 \\
1.536 \\
2.355 \\
2.781\end{array}$ & $\begin{array}{r}\text { Table VIII. } \\
\text { Descriptive by shops } \\
\text { for tracksuits }\end{array}$ \\
\hline Age & $N$ & Mean & SD & \\
\hline $\begin{array}{l}\text { Price min. ANOVA }(F=26.56 \text {; } \text { Sig }=0.000) \\
<30 \\
30-60 \\
>60 \\
\text { Total }\end{array}$ & $\begin{array}{r}359 \\
567 \\
124 \\
1,050\end{array}$ & $\begin{array}{r}8.82 \\
8.96 \\
10.22 \\
9.06\end{array}$ & $\begin{array}{l}2.065 \\
1.902 \\
1.353 \\
1.951\end{array}$ & \\
\hline $\begin{array}{l}\text { Price max. ANOVA }(F=97.79 ; \text { Sig }=0.000) \\
<30 \\
30-60 \\
>60 \\
\text { Total }\end{array}$ & $\begin{array}{r}359 \\
567 \\
124 \\
1,050\end{array}$ & $\begin{array}{l}14.79 \\
15.57 \\
18.50 \\
15.65\end{array}$ & $\begin{array}{l}2.574 \\
2.590 \\
2.332 \\
2.781\end{array}$ & $\begin{array}{r}\text { Table IX. } \\
\text { Descriptive by age } \\
\text { for tracksuits }\end{array}$ \\
\hline
\end{tabular}

being for the over 60 , with an average of $€ 18.50$ compared to the $€ 14.79$ suggested by the interviewees less than 30 .

Next, the analysis for the third product - running shoes - first for the minimum prices (Table X) and then, for the maximum prices (Table XI) proposed by the interviewees is presented.

Now, the measures of both prices and their standard deviations by gender are exposed (Table XII).

Based on the t-test of comparison of mean values, statistically significant discrepancies arise for men and women both in the average minimum price and the average maximum price suggested. This idea is ratified with the non-parametric test.

In Table XIII, the data obtained are shown, comparing the minimum and maximum prices of the interviewees by shops.

After calculating an ANOVA to assess potential differences for the three shops regarding the running shoes, as with the other products there are significant differences between the average maximum and minimum prices suggested by the customers of the different establishments. This effect is reaffirmed by carrying out a non-parametric test. The minimum price suggested by the consumers of the Shop 1 is significantly lower than those in the other two. And regarding the maximum price, the interviewees of each shop suggest different prices, the highest being in the Shop 3, which has an average over $€ 23$, compared to the $€ 18.64$ proposed by the interviewees of the Shop 1. Having carried out the calculation by shops, next, the variation by age groups is computed (Table XIV). 
SJME

23,1

\begin{tabular}{lrrrr}
\hline Minimum prices & Freq. & $(\%)$ & Accept. & Rejec. \\
\hline Euros & & & & \\
8 & 4 & 0.4 & 0.4 & 99.6 \\
9 & 13 & 1.2 & 1.6 & 98.4 \\
10 & 107 & 10.2 & 11.8 & 88.2 \\
11 & 51 & 4.9 & 16.7 & 83.3 \\
12 & 75 & 7.1 & 23.8 & 76.2 \\
13 & 65 & 6.2 & 30.0 & 6.0 \\
14 & 88 & 8.4 & 38.4 & 35.7 \\
15 & 272 & 25.9 & 64.3 & 22.4 \\
16 & 140 & 13.3 & 77.6 & 13.8 \\
17 & 90 & 8.6 & 86.2 & 5.9 \\
18 & 73 & 7.0 & 93.1 & 0.2 \\
19 & 17 & 1.6 & 94.8 & 0.1 \\
20 & 53 & 5.0 & 99.8 & 0.0 \\
21 & 1 & 0.1 & 99.9 & \\
22 & 1 & 0.1 & 100.0 &
\end{tabular}

Table X 20

Minimum price for

running shoes Total

\begin{tabular}{lrrrr}
\hline Maximum prices & Freq. & $(\%)$ & Accept. & Rejec. \\
\hline Euros & & & & \\
14 & 17 & 1.6 & 1.6 & 98.4 \\
15 & 95 & 9.0 & 10.7 & 89.3 \\
16 & 59 & 5.6 & 16.3 & 83.7 \\
17 & 57 & 5.4 & 21.7 & 72.3 \\
18 & 62 & 5.9 & 27.6 & 66.9 \\
19 & 58 & 5.5 & 33.1 & 50.0 \\
20 & 177 & 16.9 & 50.0 & 45.0 \\
21 & 53 & 5.0 & 55.0 & 34.9 \\
22 & 106 & 10.1 & 65.1 & 17.7 \\
23 & 83 & 7.9 & 73.0 & 4.7 \\
24 & 97 & 9.2 & 82.3 & 0.8 \\
25 & 137 & 13.0 & 95.3 & 0.4 \\
26 & 25 & 2.4 & 97.7 & 0.2 \\
27 & 16 & 1.5 & 99.2 & 0.0 \\
28 & 4 & 0.4 & 99.6 & \\
29 & 2 & 0.2 & 99.8 & \\
30 & 2 & 0.2 & 100.0 & \\
Total & 1,050 & 100.0 & & \\
\end{tabular}

Table XI. $\quad 29$

Maximum price for 30

running shoes

\begin{tabular}{lccc}
\hline Gender & $N$ & Mean & SD \\
\hline Price min (t test = 4.44; Sig = 0.000) & 591 & & \\
Males & 459 & 14.94 & 2.774 \\
Females & & 14.19 & 2.634 \\
Price max (t test = 2.93; Sig = 0.004) & 591 & & \\
Males & 459 & 20.99 & 3.488 \\
Females & & 20.36 & 3.444 \\
\hline
\end{tabular}

Table XII.

Descriptive by gender for running shoes
Males
Female

459
98.4

83.7

78.3

66.9

50.0

45.0

27.0

17.7

4.7

2.3

0.4

0.2

0.0 
As with the other products, significant differences are shown between the average maximum and minimum prices suggested by the customers of different ages according to ANOVA results. This outcome is confirmed by a non-parametric test. The minimum price suggested by the customers under 30 years old is significantly lower than those of the other age groups. In addition, regarding the maximum price, the interviewees of each set of ages note different prices, the costliest being those over 60 with an average of $€ 23.60$, compared to the $€ 19.03$ suggested by the interviewees under 30 (Table XV).

This table shows how revenues are very different in each shop for each price level. For example, the highest revenues for tracksuits and running shoes are achieved in the midprice level and football kit in the high-price level in Shop 1. However, the highest incomes for football kits are obtained in the mid-price level and tracksuits and running shoes in the highlevel price. Nevertheless, the highest revenues are achieved for the three products in the lowprice level in Shop 3.

\section{Discussion}

This section begins analysing the first product: the football kit. Among the minimum prices set by the interviewees, there is a high frequency at $€ 10$ (188 interviewees), achieving a great acceptation: 98.4 per cent. The maximum price which gives the greater frequency is $€ 15$. In total, 199 people consider that this is their maximum price, generating an accumulated rejection of 76.6 per cent. With the combination of these data, the acceptable price range is calculated. To do so, the greatest difference between the acceptation of the minimum price

\begin{tabular}{|c|c|c|c|c|}
\hline Shops & $N$ & Mean & $\mathrm{SD}$ & \\
\hline \multicolumn{5}{|c|}{ Price min. ANOVA $(F=62.65 ; \mathrm{Sig}=0.000)$} \\
\hline Shop 1 & 350 & 13.52 & 2.834 & \\
\hline Shop 2 & 350 & 14.62 & 2.801 & \\
\hline Shop 3 & 350 & 15.71 & 2.059 & \\
\hline Total & 1,050 & 14.62 & 2.738 & \\
\hline \multicolumn{5}{|c|}{ Price max. ANOVA $(F=207.16 ;$ Sig $=0.000)$} \\
\hline Shop 1 & 350 & 18.64 & 3.373 & \\
\hline Shop 2 & 350 & 20.38 & 3.172 & Table XIII. \\
\hline Shop 3 & 350 & 23.14 & 2.158 & Descriptive by shop \\
\hline Total & 1,050 & 20.72 & 3.481 & for running shoes \\
\hline
\end{tabular}

\begin{tabular}{|c|c|c|c|c|}
\hline Age & $N$ & Mean & SD & \\
\hline $\begin{array}{l}\text { Price min. ANOVA (F= 86.66; Sig }=0.000) \\
<30 \\
30-60 \\
>60 \\
\text { Total }\end{array}$ & $\begin{array}{r}359 \\
567 \\
124 \\
1,050\end{array}$ & $\begin{array}{l}13.30 \\
15.07 \\
16.35 \\
14.62\end{array}$ & $\begin{array}{l}2.733 \\
2.504 \\
2.060 \\
2.738\end{array}$ & \\
\hline $\begin{array}{l}\text { Price max. ANOVA }(F=107.84 ; \text { Sig }=0.000) \\
<30 \\
30-60 \\
>60 \\
\text { Total }\end{array}$ & $\begin{array}{r}359 \\
567 \\
124 \\
1,050\end{array}$ & $\begin{array}{l}19.03 \\
21.16 \\
23.60 \\
20.72\end{array}$ & $\begin{array}{l}3.592 \\
3.046 \\
2.337 \\
3.481\end{array}$ & $\begin{array}{r}\text { Table XIV. } \\
\text { Descriptive by age } \\
\text { for running shoes }\end{array}$ \\
\hline
\end{tabular}




\begin{tabular}{|c|c|c|c|c|c|c|c|}
\hline $\begin{array}{l}\text { SJME } \\
23,1\end{array}$ & Products & $\begin{array}{l}\text { Weekly sales } \\
\text { shop } 1 \text { (units) }\end{array}$ & $\begin{array}{l}\text { Revenues } \\
\text { shop } 1(€)\end{array}$ & $\begin{array}{l}\text { Weekly sales } \\
\text { shop } 2 \text { (units) }\end{array}$ & $\begin{array}{l}\text { Revenues } \\
\text { shop } 2(€)\end{array}$ & $\begin{array}{l}\text { Weekly sales } \\
\text { shop } 3 \text { (units) }\end{array}$ & $\begin{array}{l}\text { Revenues } \\
\text { shop } 3(€)\end{array}$ \\
\hline & $\begin{array}{l}\text { 1st week } \\
\text { Football kit }(€ 7) \\
\text { Tracksuit }(€ 10) \\
\text { Running shoes }(€ 10)\end{array}$ & $\begin{array}{l}38 \\
47 \\
47\end{array}$ & $\begin{array}{l}266 \\
470 \\
470\end{array}$ & $\begin{array}{r}6 \\
15 \\
8\end{array}$ & $\begin{array}{r}42 \\
150 \\
80\end{array}$ & $\begin{array}{l}106 \\
129 \\
103\end{array}$ & $\begin{array}{r}742 \\
1,290 \\
1,030\end{array}$ \\
\hline & $\begin{array}{l}\text { 2nd week } \\
\text { Football kit }(€ 15) \\
\text { Tracksuit }(€ 16) \\
\text { Running shoes }(€ 18)\end{array}$ & $\begin{array}{l}18 \\
36 \\
41\end{array}$ & $\begin{array}{l}270 \\
576 \\
738\end{array}$ & $\begin{array}{l}17 \\
22 \\
11\end{array}$ & $\begin{array}{l}255 \\
352 \\
198\end{array}$ & $\begin{array}{l}43 \\
66 \\
49\end{array}$ & $\begin{array}{r}645 \\
1,056 \\
882\end{array}$ \\
\hline $\begin{array}{l}\text { Table XV. } \\
\text { Sales and revenues }\end{array}$ & $\begin{array}{l}\text { 3rd week } \\
\text { Football kit }(€ 20) \\
\text { Tracksuit }(€ 22) \\
\text { Running shoes (€25) } \\
\text { Note: The highest re }\end{array}$ & $\begin{array}{r}14 \\
25 \\
25 \\
\text { renues for each }\end{array}$ & $\begin{array}{r}280 \\
550 \\
625 \\
\\
\text { hop and pro }\end{array}$ & $\begin{array}{c}6 \\
18 \\
11 \\
\\
\text { luct are in italic }\end{array}$ & $\begin{array}{l}120 \\
396 \\
275\end{array}$ & $\begin{array}{l}8 \\
7 \\
7\end{array}$ & $\begin{array}{l}160 \\
154 \\
175\end{array}$ \\
\hline
\end{tabular}

and the rejection of the maximum price is sought, as it was aforementioned in the direct method. In this way, an acceptable price range between $€ 8$ and $€ 12$ and the most appropriate price is obtained, or that which obtains a greater acceptation, is $€ 10$.

Having delineated the acceptable price range and the price recommended for the first product, the authors analyse these prices suggested according to different variables. The first is gender. The average of the minimum prices is lower for men than for women, though not significantly. We get the same result with the maximum prices. Another of the examined variables the point of sale. Hence, according to the geographical situation of the point of sale, it can be clearly seen that the minimum and maximum prices proposed are lower in the Shop 1 than in the Shop 2, and these are lower than in the Shop 3. This is the same as with the price limits of each shop. The last variable analysed for the first product is age. These measures vary considerably. Those who give a lower value to the maximum and minimum prices are under 30 years old, and these values increase with the age.

According to these results, if 100 units of product were sold at the maximum price that customers are willing to pay in each store, store 1 would bill for 1597 euros, store 2 would bill for 1380 euros and store 3 would bill for 1169 euros. This is a total of 4146 euros. However, if the price of $10 €$ were set for the three shops the total bill would be 3000 euros. Therefore, considering the demand for this product in each store and adapting the price to each one will produce 38.3 per cent more incomes than fixing the same price for the three. This fact highlights the importance of fixing prices taking into account the demand of each shop, as other studies support in other contexts (Kimes and Wirtz, 2002).

Analysing the surveys regarding the tracksuit, the most frequent price is $10 €$ (245 interviewees) and this value achieves a 79.7 per cent acceptation. The same analysis is carried out with the maximum price. The highest frequency is $€ 15$, although in this case the acceptation is 46.1 per cent. The acceptable price range is calculated, seeking the greatest difference between the acceptation of the minimum price and the rejection of the maximum price. An acceptable price range between $€ 10$ and $€ 14$ is obtained, and the recommended or optimum price is $€ 12$. 
Next, the price averages according to the interviewee's gender are examined. For men, the minimum price is $€ 9.34$ and for women $€ 8.70$. Therefore, men have a price reference significantly greater than women. The same occurs with the maximum price: for men, it is $€ 16$ and for women $€ 15.20$. Later, the suggested averages of prices according to the different points of sale are analysed. The same thing happens to the tracksuits and the kits: the average prices are lower among the customers of the Shop 1 than among those of the Shop 2 , and all these are lower than those of the Shop 3. This occurs with both the minimum price and the maximum price. With regards to age ranges, both in the minimum price and the maximum price, the higher age the higher prices. The average minimum price is $€ 8.82$ and the maximum $€ 14.79$ for under-30s. For those of age between 30 and 60 years old, the minimum is $€ 8.96$ and the maximum $€ 15.77$. Finally, those over-60s have the highest maximum and minimum prices $€ 10.22$ and $€ 18.50$, respectively. According to ANOVA, it is confirmed that these differences are statistically significant and higher in the range of over60 s with regards to the other age groups.

Following the same reasoning for this product than for the football kit, considering the demand for the tracksuit in each store and adapting the price to each one will produce 30.39 per cent more incomes than fixing the same price for the three shops.

Finally, the third product: running shoes is analysed. In reference to the minimum price, 272 interviewees consider $€ 15$ to be a good minimum price, with an acceptation of 64.3 per cent. The most accepted maximum price is $€ 20$ for 177 interviewees, with an acceptation percentage of 50 per cent. The acceptable price range is from $€ 16$ to $€ 19$ and the recommendable or optimum price is $€ 18$.

In this product, again there are significant differences between the averages of the suggested prices. For men, the minimum price is $€ 14.99$ and the maximum $€ 20.99$. For women, these are $€ 14.19$ and $€ 20.36$, respectively. The $t$ test shows that this is a statistically significant difference. In reference to the points of sale, the same happens as to the previous cases, the lowest minimum and maximum prices are in the Shop 1: $€ 13.52$ and $€ 18.64$, respectively. The second lowest are in the Shop $2-€ 19.62$ and $€ 20.38$ - and as has happened in the previous cases the shop which obtains the highest average prices is the 3 : $€ 15.71$ for the minimum price and $€ 23.19$ for the maximum price. From the ANOVA, the given results provide significant differences both for the minimum and for the maximum price. Last, the results differentiated by the age ranges are analysed. The same happens with the running shoes as with the kits and the tracksuits: as the age increases so do the averages of the interviewees' maximum and minimum prices. In the under 30 years old range, the average minimum is $€ 13.30$ and the average maximum is $€ 19.03$. For the 30 to 60 years old range, these are $€ 15.07$ and $€ 21.16$. For the over 60 years old, they are $€ 16.35$ and $€ 23.60$, respectively. These differences can be considered significant according to the ANOVA for all the age groups in both the maximum and the minimum prices.

Following the same reasoning for this product than for the previous ones, considering the demand for the running shoes in each store and adapting the price to each one will produce 15.11 per cent more incomes than fixing the same price for the three shops.

All these figures show the idea that pricing policies need to be appropriately malleable for price optimisation in reality (Watson et al., 2015). Furthermore, managers who want to create price perception should develop a positive lasting first impression of their stores, especially in shops were price sensitivity is higher (as Shop 3 in our case) (Cho, 2014). In addition, recent literature indicates that dynamic messages, such as videos, create a stronger emotional connection, which consequently reduces clients' price sensitivity (Grewal et al., 2017; Roggeveen et al., 2015). As a result, this is another tool retailers' managers could handle to influence customers' price sensitivity. 
SJME

23,1

\section{Conclusions}

The foremost contribution of this article is to demonstrate empirically how considering the local demand at setting prices would generate larger earnings, even for a small retail chain. The direct method of setting acceptable prices enables us to set the prices according to the demand. The best option is if these prices are above the costs. It can be noted that the prices should be set according to each shop, and a different price used in each point of sale to maximise profits and to adapt to what the typical customer of each shop is willing to pay. Despite the products being the same and the points of sale belonging to the same retail chain, the knowledge of the product, both in its technical characteristics and in knowing other offers of the competition in related products, gives rise to the minimum price suggested being lower.

On the other hand, the differences obtained in the different points of sale are significant. The conclusion drawn from this aspect is that there is not a unique acceptable price range or recommended price. Rather this depends on the location of each sales point. The point where the lower minimum and maximum suggested prices are obtained is Shop 1. Despite the fact is not the city with the lowest average incomes per person. There are several reasons for this: it is within a Factory Outlet, which has a lot of competition in the zone; it is situated in an urban area near the province capital; and it is visited by many people. Therefore, one can think that the customers who go to this establishment are more price-sensitive, and it can be deduced that they will base their shopping decision more on the price than customers who are less sensitive. The latter will tend to seek offers and discounts to make their purchase (Petrick, 2005). The closest in prices is the point of sale in self-esteem from fortunes of others.

Shop 2, a rural area of about 20,000 inhabitants around 30 kilometres from the province capital, in which the competition is lower. The citizens of this town have the lowest average income of the three places analysed. As it is further from Seville, the consumer can consider paying a little more for the product. Finally, the Shop 3 in Seville is in a tourist area and has an ample public which is made up of both tourists and residents in the city centre with the highest average incomes. This means that the consumers have a higher average purchasing power. In addition, as there is not much competition close by, the prices suggested by the customers are higher. This study confirms the result of O'Neill and Lambert (2001), they demonstrated that the greater the importance for the customer of buying cheap, the smaller the size of the acceptable price range. This determines a greater sensitivity to the price as the customer is more likely to buy in promotions.

Furthermore, some relevant conclusions regarding the buyers' ages are found. The price is a very important factor in the purchasing decision of the product and some differences between ages exist. The differences between these three groups are very significant. The range under 30 years old is more inclined to suggest low minimum prices. Therefore, they are more sensitive to the prices of the three products. It is significant that the $30-60$ years old range, usually people with a greater knowledge of the product, is inclined to seek zones with much competition where a better price can be obtained. It also tends to be the age group with more possibilities of movement, having their own car. Lastly, the people in the over 60 years old age range are less inclined to travel far to acquire the product and are also the ones who have a more stable economic capacity. These reasons are the ones that explain the results of the surveys in which this age range is the one which chooses a higher maximum and minimum price and is therefore the age group that is least price sensitive.

The foremost contribution of this study is to reveal empirically how considering the local demand at fixing prices would produce bigger incomes, more than 30 per cent in some products, even for a small retail chain. The benefits of demand-based pricing are well documented in terms of customer satisfaction and loyalty (Heo et al., 2013; Kimes and Wirtz, 2002). 
Nevertheless, the studies of the effects of these pricing policies on firm incomes are scarce. Managers could improve significantly firm incomes in retailing sector adapting pricing policies typically applied in service sector.

To finish, and as a general idea of the study, the acceptable price range is not unique, each point of sale may have a different one because it depends on numerous factors: competition, the economic capacity of the nearest residents, the geographical situation of the sales point, the capacity of attracting customers, or shopping environment (Campbell and Fairhurst, 2016). In addition, in the results obtained in the surveys the acceptable intervals are relevant but not totally certain. Because of the buyers acting on impulses corresponding to their economic capacity, perception of the sales point, of the product and numerous other aspects. These impulses are difficult to forecast, so it might be considered the acceptable price range as the best way of setting the price of a new product in the market.

This direct method of setting acceptable prices enables us to set the prices according to the demand. The best option is if these prices are above the costs. It can be noted that the prices should be set according to each shop, and a different price used in each point of sale to maximise profits. In addition, to adapt to what the typical customer of each shop is willing to pay, despite the products being the same and the points of sale belonging to the same retail chain. This pricing policy might provoke dissatisfaction of consumers that can occur if they know that the prices are different in the shops, especially if they pay a higher price. Although this pricing discrimination is usual in other industries, such as accommodation, flights, etc., is not so used in small retailing chains. It would be an interesting future research to analyse customers' perceptions of pricing discrimination in this type of retailers.

Among the limitations of this work can be highlighted the local character of the analysed chain. Furthermore, this study has been carried out with only three products of an unknown brand to avoid the brand effect. In addition, similar research could be done in other countries, or group of countries at similar levels of commercial development and to investigate if they achieve similar results. Another future research is to analyse how cultural differences influence customers' price sensitivity.

\section{References}

Calabrese, A. and De Francesco, F. (2014), "A pricing approach for service companies: service blueprint as a tool of demand-based pricing", Business Process Management Journal, Vol. 20 No. 6, pp. 906-921.

Campbell, J.M. and Fairhurst, A.E. (2016), "Reducing the intention to behaviour gap for locally produced foods purchasing: the role of store, trust, and price", International Journal of Retail and Distribution Management, Vol. 44 No. 5, pp. 508-523.

Carpenter, J.M. and Moore, M. (2006), "Consumer demographics, store attributes, and retail format choice in the US grocery market", International Journal of Retail and Distribution Management, Vol. 34 No. 6, pp. 434-452.

Cebollada-Pascual, J. and Mugica-Grijalba, J.M. (1997), "La gestion De los precios Y promociones En La empresa minorista”, Distribución y Consumo, Vol. 33, pp. 1-11.

Chang, H.H. and Wong, K.H. (2018), "Consumer psychological reactance to coalition loyalty program: price-consciousness as a moderator", Service Business, pp. 1-24.

Cho, Y.K. (2014), "Service quality and price perceptions by internet retail customers: linking the three stages of service interaction", Journal of Service Research, Vol. 17 No. 4, pp. 432-445.

Dodds, W.B., Monroe, K.B. and Grewal, D. (1991), "Effects of price, brand, and store information on buyers", Journal of Marketing Research, Vol. 28 No. 3, pp. 307-319. 
Fassnacht, M. and El Husseini, S. (2013), "EDLP versus hi-Lo pricing strategies in retailing - a state of the art article", Journal of Business Economics, Vol. 83 No. 3, pp. 259-289.

Finnegan, C., Runyan, R.C., Gonzalez-Padron, T. and Hyun, J. (2016), "Diversity and rigor trends in retailing research: assessment and guidelines", International Journal of Management Reviews, Vol. 18 No. 1, pp. 51-68.

Fisher, M., Gallino, S. and Li, J. (2017), "Competition-based dynamic pricing in online retailing: a methodology validated with field experiments", Management Science, Vol. 64 No. 6, pp. 2496-2514.

Grewal, D., Roggeveen, A.L. and Nordfält, J. (2017), "The future of retailing”, Journal of Retailing, Vol. 93 No. 1, pp. 1-6.

Gupta, S. and Kim, H.W. (2010), "Value-driven internet shopping: the mental accounting theory perspective sumeet", Psychology and Marketing, Vol. 27 No. 1, pp. 13-35.

Heo, C.Y., Lee, S., Mattila, A. and Hu, C. (2013), "Restaurant revenue management: do perceived capacity scarcity and price differences matter?", International Journal of Hospitality Management, Vol. 35, pp. 316-326.

Huddleston, P., Whipple, J., Nye Mattick, R. and Jung Lee, S. (2009), "Customer satisfaction in food retailing: comparing specialty and conventional grocery stores", International Journal of Retail and Distribution Management, Vol. 37 No. 1, pp. 63-80.

Kalyanaram, G. and Little, J.D.C. (1994), "An empirical analysis of latitude of price acceptance in consumer package goods", Journal of Consumer Research, Vol. 21 No. 3, pp. 408-418.

Karani, K.S., Fraccastoro, K. and Shelton, J. (2013), "The effect of order of prices on customers' confidence levels", Journal of Management and Marketing Research, Vol. 13,p. 1.

Kimes, S.E. and Wirtz, J. (2002), "Perceived fairness of demand-based pricing for restaurants", Cornell Hotel and Restaurant Administration Quarterly.

Kosenko, R. (2015), "Brand name effect on price thresholds: manipulating consumer price knowledge", Proceedings of the 1988 Academy of Marketing Science (AMS) Annual Conference, Springer, pp. 67-71.

McCarthy, E.J. (1964), "Basic marketing: a managerial approach”, Academy of Marketing Science.

Macé, S. (2012), "The impact and determinants of nine-ending pricing in grocery retailing", Journal of Retailing, Vol. 88 No. 1, pp. 115-130.

Martín-Consuegra, D., Molina, A. and Esteban, Á. (2007), “An integrated model of price, satisfaction and loyalty: an empirical analysis in the service sector", Journal of Product and Brand Management, Vol. 16 No. 7, pp. 459-468.

Mazumdar, T., Raj, S.P. and Sinha, I. (2005), "Reference price research: review and propositions", Journal of Marketing, Vol. 69 No. 4, pp. 84-102.

Menon, R.G.V., Sigurdsson, V., Larsen, N.M., Fagerstrøm, A. and Foxall, G.R. (2016), "Consumer attention to price in social commerce: eye tracking patterns in retail clothing", Journal of Business Research, Vol. 69 No. 11, pp. 5008-5013.

Monroe, K. (1990), Pricing, Making Profitable Decisions, McGraw-Hill, New York, NY.

Monroe, K.B. (1973), "Buyers' subjective perceptions of price”, Journal of Marketing Research, Vol. 10 No. 1, pp. 70-80.

Monroe, K.B., Rikala, V.M. and Somervuori, O. (2015), "Examining the application of behavioral price research in business-to-business markets", Industrial Marketing Management, Vol. 47, pp. 17-25.

Nagle, T.T. and Müller, G. (2017), The Strategy and Tactics of Pricing: A Guide to Growing More Profitably, Routledge, New York.

Nagle, T.T., Hogan, J. and Zale, J. (2016), The Strategy and Tactics of Pricing: New International Edition, Routledge, New York.

O'Neill, R.M. and Lambert, D.R. (2001), “The emotional side of price”, Psychology and Marketing, Vol. 18 No. 3, pp. 217-237. 
Pauwels, K., Srinivasan, S. and Franses, P.H. (2007), "When do price thresholds matter in retail categories?”, Marketing Science, Vol. 26 No. 1, pp. 83-100.

Pelegrin-Borondo, J., Juaneda-Ayensa, E., Arias-Oliva, M. and González-Menorca, C. (2014), "Umbrales psicológicos de precios: modelo de valoración de la oferta competitiva”, Cuadernos de Estudios Empresariales, Vol. 24, pp. 75-105.

Petrick, J.F. (2005), "Segmenting cruise passengers with price sensitivity", Tourism Management, Vol. 26 No. 5, pp. 753-762.

Rice, D.H., Fay, S.A. and Xie, J. (2014), "Probabilistic selling vs markdown selling: price discrimination and management of demand uncertainty in retailing", International Journal of Research in Marketing, Vol. 31 No. 2, pp. 147-155.

Roggeveen, A.L., Grewal, D., Townsend, C. and Krishnan, R. (2015), "The impact of dynamic presentation format on consumer preferences for hedonic products and services", Journal of Marketing, Vol. 79 No. 6, pp. 34-49.

Rondán Cataluña, F.J. (2004), "Price discrimination in retailing", International Journal of Retail and Distribution Management, Vol. 32 No. 4, pp. 205-215.

Rosa-Díaz, I.M. and Rondan-Cataluña, F.J. (2012), "Determinantes y consecuencias de la efectividad de las promociones basadas en precios", Cuadernos de Gestion, Vol. 12 No. 2, pp. 15-42.

Rosa-Díaz, I.M., Rondan-Cataluña, F.J. and Diez-de Castro, E.C. (2013), Gestión de Precios, Esic Editorial, Madrid.

Ruiz-Real, J.L., Gázquez-Abad, J.C., Esteban-Millat, I. and Martínez-López, F.J. (2018), "Betting exclusively by private labels: could it have negative consequences for retailers?", Spanish Journal of Marketing - ESIC, Vol. 22 No. 2, pp. 183-202.

Rusetski, A., Andrews, J. and Smith, D.C. (2014), "Unjustified prices: environmental drivers of managers' propensity to overprice", Journal of the Academy of Marketing Science, Vol. 42 No. 4, pp. $452-469$.

Sherif, M., Taub, D. and Hovland, C.I. (1958), "Assimilation and contrast effects of anchoring stimuli on judgments", Journal of Experimental Psychology, Vol. 55 No. 2, pp. 150-155.

Srinivasan, S., Pauwels, K. and Nijs, V. (2008), "Demand-based pricing versus past-price dependence: a cost-benefit analysis", Journal of Marketing, Vol. 72 No. 2, pp. 15-27.

Unni, R., Tseng, and Pillai, D. (2010), "Context specificity in use of price information sources", Journal of Consumer Marketing, Vol. 27 No. 3, pp. 243-250.

Uusitalo, O. and Rökman, M. (2007), "The impacts of competitive entry on pricing in the Finnish retail grocery market", International Journal of Retail and Distribution Management, Vol. 35 No. 2, pp. 120-135.

Verhoef, P.C., Kannan, P.K. and Inman, J.J. (2015), "From multi-channel retailing to omni-channel retailing: introduction to the special issue on multi-channel retailing", Journal of Retailing, Vol. 91 No. 2, pp. 174-181.

Verhoeven, J.W.M., van Rompay, T.J.L. and Pruyn, A.T.H. (2009), "The price facade: symbolic and behavioral price cues in service environments", International Journal of Hospitality Management, Vol. 28 No. 4, pp. 604-611.

Watson, I., Wood, S. and Fernie, J. (2015), “Passivity': a model of grocery retail price decision-making practice", European Journal of Marketing, Vol. 49 Nos 7/8, pp. 1040-1066.

\section{Corresponding author}

F. Javier Rondan-Cataluña can be contacted at: rondan@us.es

For instructions on how to order reprints of this article, please visit our website:

www.emeraldgrouppublishing.com/licensing/reprints.htm

Or contact us for further details: permissions@emeraldinsight.com 